\title{
Biochemical Analysis, Yield of Agar and its Physical and Chemical Characteristics of Marine Red Seaweeds of Hypnea musciformis (Wulfen) J. V. Lamouroux, Hypnea pannosa J. Agardh, Hypnea valentiae (Turner) Montagne from Karachi Coast
}

\author{
Rashida Qari ${ }^{1 *}$ and Saima Haider ${ }^{2}$ \\ ${ }^{1}$ School of Maritime Sciences, Bahria University, Karachi Campus, Pakistan \\ ${ }^{2}$ Institute of Marine Science, University of Karachi, Pakistan \\ *Corresponding Author: Rashida Qari, School of Maritime Sciences, Bahria \\ University, Karachi Campus, Pakistan.
}

Received: March 06, 2020

Published: May 11, 2020

(C) All rights are reserved by Rashida Qari and Saima Haider.

\begin{abstract}
Seasonal variation in agar yield and some agar physical and chemical properties and biochemical composition of all studied species were examined in different periods 2014 to 2016 . The maximum agar yields of all studied species were recorded during the winter and minimum values were obtained during the summer. Agar yield of $H$. musciformis varied from a minimum of $17.80 \%$ (dry $\mathrm{wt}$ ) in May, to a maximum value of $30 \%$ in October while that of $H$. pannosa varied from a minimum of $18.60 \%$ (dry wt) at October, to a maximum of $35.80 \%$ at January and the yield of agar in $H$. valentiae varied from a minimum of $20.80 \%$ (dry wt) in April, to a maximum value of $35 \%$ in October like the H. musciformis. The maximum agar gel strength was recorded in H. valentiae (130 g/cm2) as compared to other species (H. musciformis and H. pannosa). Gel density, viscosity, temperature and melting temperature showed significant seasonal variation for all three studied seaweed species. Agar yield and quality of all three species were within the range of accepted commercial values. An intensive spectroscopic FTIR technique used to identify the frequency of functional groups alcohols, amines and alkanes $(\mathrm{O}-\mathrm{H}, \mathrm{N}-\mathrm{H}, \mathrm{C}-\mathrm{H})$, alkynes and nitriles $(\mathrm{C} \equiv \mathrm{C}, \mathrm{C} \equiv \mathrm{N})$, carbonyl amide, nitro methane and aromatic $(\mathrm{C}=\mathrm{O}, \mathrm{N}=\mathrm{O})$, alkane (C-C), sulfoxides ( $\mathrm{S}=0$ ), alkene $(\mathrm{C}-\mathrm{H})$ and alkyl halide $(\mathrm{C}-\mathrm{Cl})$ in all three species of Hypnea (H. musciformis, H. pannosa, H. valentiae). The carbohydrate content was in the range of $20-30 \%$ for all studied species while the ash content was in the range of $10-20 \%$. The results indicated that all three studied species can be considered as a good aspirant for commercial agar use.
\end{abstract}

Keywords: Agar; Red Seaweed; FTIR; Gel Properties; Karachi Coast

\section{Introduction}

Seaweed or marine plants are considered as important living and the good source of natural product having many applications in various industries. They are the only source for the production of agar, carrageenan and alginic acid [1]. It has been estimated that the world's resources of seaweeds comprises 1460 million tons wet weight of brown algae and 261 million tons wet weight red algae and the total production of seaweeds is about $1721 \times 10^{4}$ tons wet weight annually [2]. Agar is a gel forming polysaccharide with a sugar residue as a principal chain consisting of 1,3-linked ß-D-galactopyranose, 1,4-linked 3,6 anhydro- $\alpha$-L-galactopyranose units forming a cross-linked network model while agarobiose is the basic disaccharide representing the structural unit of all agar polysaccharides [3]. Agar have been always used as gelling, stabilizing and thickening agents in the food, confectionary, textiles, pharmaceuticals, dairy and paper industry [4].
Most commonly agar is synthesized by a number of seaweeds species under the class Rhodophyceae mainly depend on order Gracilariales and Gelidiales [5]. The yield and quality of agar not only depend on its specific characteristic but it is varied with species and time of collection also [6]. The genus Hypnea is well known within the family Cystocloniaceae of the order Gigartinales [4]. The genus is widely distributed in the warm and temperate seas. Hypnea musciformis, Hypnea pannosa and Hypnea valentiae are the resources of both agar and carrageenan [4,7]. Mouradi., et al. [8] studied seasonal variation of the growth, chemical composition and carrageenan extracted from Hypnea musciformis (Wulfen) Lamouroux harvested along the Atlantic coast of Morocco.

Seaweeds also contain carbohydrates, protein, amino acids, iodine, bromine, and vitamins [2]. Seasonal variation in biomass and agar quality extracted from the marine red algae Pterocladia 
Biochemical Analysis, Yield of Agar and its Physical and Chemical Characteristics of Marine Red Seaweeds of Hypnea musciformis (Wulfen) J. V. Lamouroux, Hypnea pannosa J. Agardh, Hypnea valentiae (Turner) Montagne from Karachi Coast

capillacea and Hypnea musciformis growing along Mediterranean seashore of Alexandria, Egypt were studied by Fathy and Mohammady [6]. The Hypnea valentiae (Turner) Montagne due to its importance farmed at Minicoy Lagoon (Lakshadweep) [4].

\section{Aim of the Study}

The aim of present study is to investigate the variations in agar yield and its physical, chemical properties and evaluate their potential nutritive value of three abundantly found species of genus Hypnea: H. musciformis, H. pannosa and H. valentiae of the Karachi coast of Pakistan.

\section{Materials and Methods}

The monthly fresh samples of three species of red seaweeds Hypnea musciformis (Wulfen) J. V. Lamouroux, Hypnea pannosa J. Agardh, Hypnea valentiae (Turner) Montagne were collected from four different exposed sites of Karachi coast (Buleji, Hawks Bay, Manora and Paradise Point) in different periods between 2014 2016. The sampling of seaweeds was done from Buleji and Hawks Bay during January 2014 to December 2014, from Manora during January 2015 to December 2015 and from Paradise Point during January 2016 to December 2016 at low tide except few months. All the samples of seaweeds collected were placed separately in pre-labeled plastic bags and brought to the laboratory, carefully cleaned from mud debris and other epiphytes with filtered seawater and identified (Table 1).
The yield of agar was extracted by the non-alkali method described by Praiboon., et al. [9] and its physical properties (Gel density, viscosity, gelation temperature, melting point, and gel strength) were determined by the method of Whyte and Engler [10]. The FTIR analysis technique was used for investigating the functional groups in seaweed samples [11]. The carbohydrate content was estimated by using phenol sulfuric acid method [12] and ash or total inorganic content was determined by the standard method of A.O.A.C [13].

\section{Result and Discussion}

The sites of Karachi coast Buleji, Hawks Bay, Manora and Paradise Point are rich in macro algae or seaweeds. Table 2 show total one hundred four $(\mathrm{n}=104)$ individuals of Hypnea (Hypnea musciformis, Hypnea pannosa and Hypnea valentiae) of family Hypneaceae were sampled during the study period from all four sites. Samples collected from Buleji $(n=31)$, Hawks Bay $(n=19)$, Manora ( $\mathrm{n}=29$ ) and Paradise Point $(\mathrm{n}=25)$. Total 39 individual sample of H. musciformis were collected from Buleji $(\mathrm{n}=12)$, Hawks Bay ( $\mathrm{n}=$ $7)$, Manora $(\mathrm{n}=11)$ and Paradise point $(\mathrm{n}=9), H$. pannosa $(\mathrm{n}=28)$ from Buleji (8), Hawks Bay $(\mathrm{n}=5)$, Manora $(\mathrm{n}=8)$ and Paradise point $(\mathrm{n}=7)$ and $H$. valentiae $(\mathrm{n}=37)$ from Buleji $(\mathrm{n}=11)$, Hawks Bay ( $n=7)$, Manora $(n=10)$ and Paradise Point $(n=9)$. The study data reveals high variability in the number of individuals in each species and site (Table 2).

\begin{tabular}{|l|c|c|c|c|c|c|c|c|}
\hline S. No & Kingdom & Division & Class & Order & Family & Genus & Species & Collection Site \\
\hline 1 & Protista & Rhodophyta & Bangiophyceae & Bangiales & Hypneaceae & Hypnea & Hypnea musciformis & $\begin{array}{c}\text { Buleji, Hawks Bay, Manora, } \\
\text { Paradise Point }\end{array}$ \\
\hline 2 & - & & & & & & Hypnea pannosa & $\begin{array}{c}\text { Buleji, Hawks Bay, Manora, } \\
\text { Paradise Point }\end{array}$ \\
\hline 3 & - & & & & & - & Hypnea valentiae & $\begin{array}{c}\text { Buleji, Hawks Bay, Manora, } \\
\text { Paradise Point }\end{array}$ \\
\hline
\end{tabular}

Table 1: Seaweed species of Hypnea collected from Karachi coast.

\begin{tabular}{|l|c|c|c|c|c|c|}
\hline S. No. & Name of Species & Buleji & Hawks Bay & Manora & Paradise Point & Total \\
\hline 1 & Hypnea musciformis & 12 & 7 & 11 & 9 & 39 \\
\hline 2 & Hypnea pannosa & 8 & 5 & 8 & 7 & 28 \\
\hline 3 & Hypnea valentiae & 11 & 7 & 10 & 9 & 37 \\
\hline & Total & 31 & 19 & 29 & 25 & 104 \\
\hline
\end{tabular}

Table 2: Total number of individuals of red seaweeds species collected from Karachi coast.

The range of total agar content in all studied species was 17.80 - $35.80 \%$ with the mean value of $25.4 \pm 3.37 \%$. The concentration of agar was mostly high in winter season (Nov-January). The figure 1 showed that agar concentration decreased from January to August and again increased till December. Whereas the highest agar mean value extracted from $H$. valentiae $(27.35 \pm 3.20 \%)$ followed by Hypnea pannosa $(26.67 \pm 3.07 \%)$ and $H$. musciformis $(22.18 \pm$ $0.92 \%$ ) (Figure 2). It is also noted that content of agar was obtained in Buleji samples as compared to other three sites samples (Figure $3)$. 


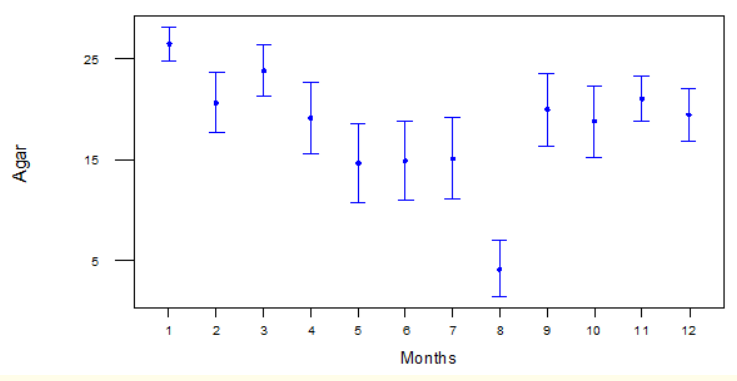

Figure 1: Monthly variations in agar content (\% dry wt) of $H$. musciformis, H. pannosa and H. valentiae of Karachi coast.

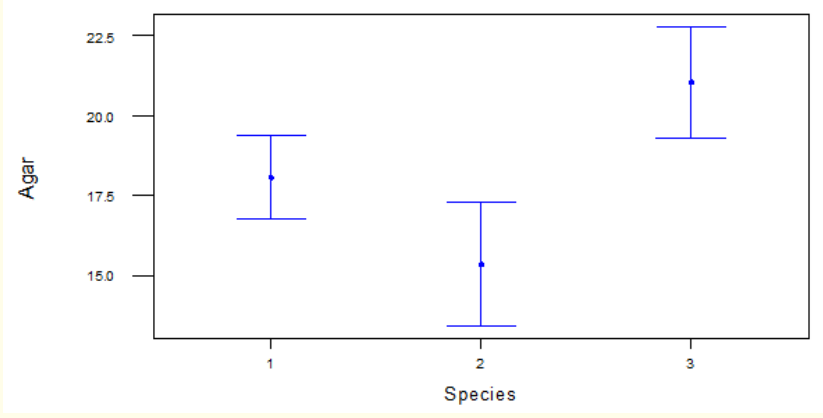

Figure 2: Variations in agar content ( $\%$ dry wt) of H. musciformis, H. pannosa and $H$. valentiae of Karachi coast.

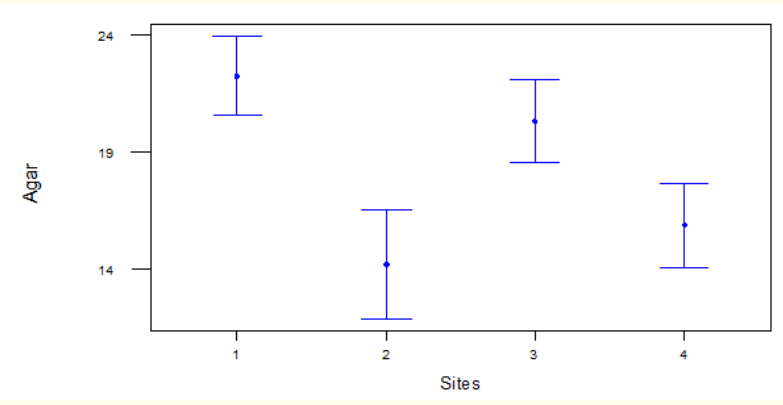

Figure 3: Variations in agar content (\% dry wt) of $H$. musciformis, H. pannosa and H. valentiae collecting from different sites (Buleji, Hawks Bay, Manora and Paradise Point) of Karachi coast.

H. musciformis was found most of month of the year at all sites. The range of agar content in H. musciformis was $17.80-30 \%$ with mean concentration of $22.18 \pm 0.92 \%$. In $H$. musciformis agar concentration varied throughout the years. In Buleji sample it was high in October (30\%) and in Hawks Bay sample it was high (24.20\%) in December. Whereas in Manora sample it was high in March (27.88\%) and in Paradise Point sample in September (26\%)
(Figure 4). H. pannosa was found in most of the period of year from all studying sites (Buleji, Hawks Bay, Manora and Paradise Point). The range of agar content in H. pannosa was $22-35.80 \%$ with mean concentration value of $26.67 \pm 3.07 \%$. Like other species $H$. pannosa agar concentration also varied throughout the years in all sites samples such as it was high in March (33.70\%) in Buleji samples, in January (35.80\%) in Hawks Bay samples, in April (33\%) in Manora samples and in February (28\%) in Paradise Point samples (Figure 5). $H$. valentiae was found most of the time in the year at Buleji, Hawks Bay, Manora and Paradise Point. The range of agar content in $H$. valentiae was $20.80-35 \%$ with mean concentration value of $27.35 \pm 3.20 \%$. In Buleji samples agar concentration was high in October (35\%) and in Hawks Bay samples it was high (34.25\%) in January. In Manora sample it was high in June (32\%) and in Paradise Point sample it was high (26\%) in August (Figure 6).

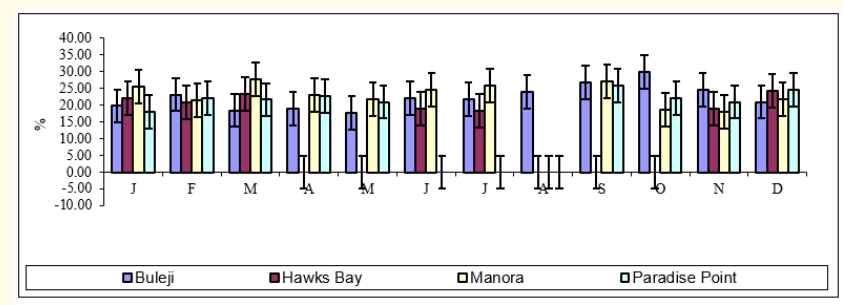

Figure 4: Seasonal variations in the yield of agar from H. musciformis collecting from Karachi coast.

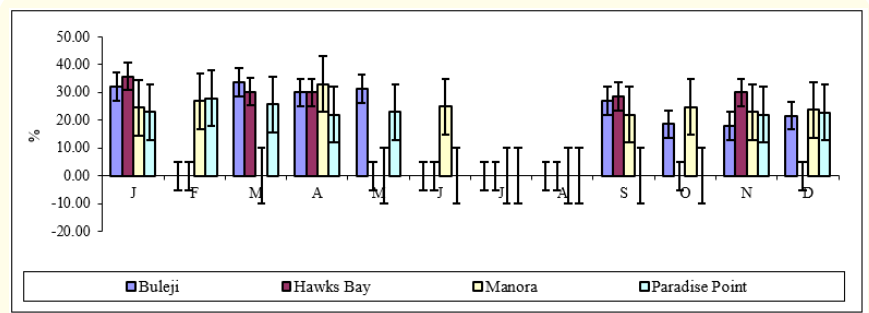

Figure 5: Seasonal variations in the yield of agar from H. pannosa collecting from Karachi coast.

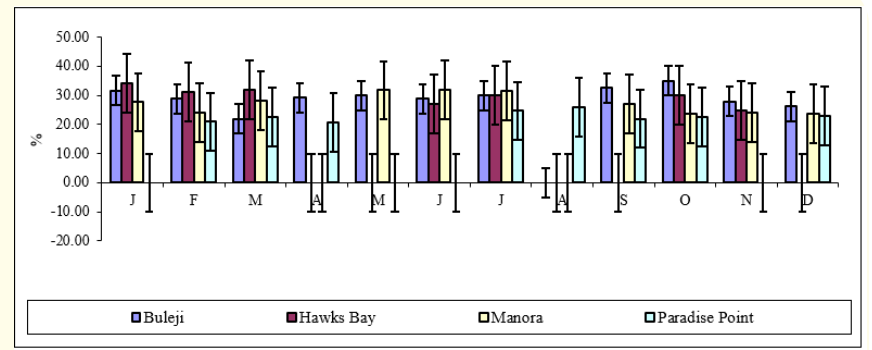

Figure 6: Seasonal variations in the yield of agar from H. valentiae collecting from Karachi coast. 
Biochemical Analysis, Yield of Agar and its Physical and Chemical Characteristics of Marine Red Seaweeds of Hypnea musciformis (Wulfen) J. V. Lamouroux, Hypnea pannosa J. Agardh, Hypnea valentiae (Turner) Montagne from Karachi Coast

The density of agar extract in H. musciformis was in a range of $0.70-1.44 \mathrm{~g} / \mathrm{cm}^{3}$ in all sites samples. In both Buleji and Paradise Point samples density was high in September $\left(1.35 \mathrm{~g} / \mathrm{cm}^{3}\right.$ and 1.44 $\mathrm{g} / \mathrm{cm}^{3}$ respectively) in Hawks Bay samples it was high in December $\left(1.08 \mathrm{~g} / \mathrm{cm}^{3}\right)$ whereas in Manora sample it was high $\left(1.08 \mathrm{~g} / \mathrm{cm}^{3}\right)$ in March (Table 3). The gel viscosity of $H$. musciformis agar extract was in the range of $45-134 \mathrm{cP}$. Viscosity of agar was high in October (113 cP) in Buleji samples, in December (106 cP) in Hawks Bay samples, in March (70 cP) in Manora samples and in September (134 cP) in Paradise Point samples (Table 3). Gel temperature of H. musciformis was in the range of $38-101^{\circ} \mathrm{C}$. In Buleji samples gel temperature was high in October $\left(101^{\circ} \mathrm{C}\right)$ and in Hawks Bay samples it was high in December $\left(65^{\circ} \mathrm{C}\right)$ whereas in both Manora and Paradise Point samples gel temperature was high $\left(57^{\circ} \mathrm{C}\right.$ and $86^{\circ} \mathrm{C}$ respectively) in September (Table 4). H. musciformis extract gel melting point was in the range of $245-671^{\circ} \mathrm{C}$, high in October $\left(607^{\circ} \mathrm{C}\right)$ in Buleji samples, in December $\left(391^{\circ} \mathrm{C}\right)$ in Hawks Bay samples, in March $\left(380^{\circ} \mathrm{C}\right)$ in Manora samples and in September $\left(671^{\circ} \mathrm{C}\right)$ in Paradise Point samples (Table 4). Gel strength was in the range of $100-120 \mathrm{~g} / \mathrm{cm}^{2}$. The highest gel strength was found in Paradise Point samples $\left(120 \mathrm{~g} / \mathrm{cm}^{2}\right)$ as compared to other studied site samples (Figure 7). The density of agar extract in $H$. pannosa was in a range of $0.58-1.21 \mathrm{~g} / \mathrm{cm}^{3}$ in all sites samples. In Buleji and Hawks Bay samples it was high in January $\left(1.04 \mathrm{~g} / \mathrm{cm}^{3}\right.$ and $1.00 \mathrm{~g} /$ $\mathrm{cm}^{3}$ respectively), in Paradise Point samples in February (1.21 g/ $\mathrm{cm}^{3}$ ) and in Manora samples in April $\left(1.44 \mathrm{~g} / \mathrm{cm}^{3}\right.$ ) (Table 5). The gel viscosity of $H$. pannosa agar extract was in the range of $75-122$ cP. In Buleji samples viscosity of agar was high in March (136 cP), in Hawks Bay samples it was high (110 cP) in January whereas in both Manora and Paradise Point samples gel viscosity was high in February (122 cP) and $120 \mathrm{cP}$ respectively (Table 5). Gel tempera- ture of $H$. pannosa was in the range of $28-76^{\circ} \mathrm{C}$. In Buleji samples gel temperature was high in March $\left(53^{\circ} \mathrm{C}\right)$, in Hawks Bay samples in January $\left(58^{\circ} \mathrm{C}\right)$, in Manora samples in April $\left(72^{\circ} \mathrm{C}\right)$ and in Paradise Point samples in February $\left(76^{\circ} \mathrm{C}\right.$ ) (Table 6). H. pannosa gel melting point was in the range of $128-540^{\circ} \mathrm{C}$. In Buleji samples gel melting point was high in March $\left(240^{\circ} \mathrm{C}\right)$, in Hawks Bay samples in January $\left(280^{\circ} \mathrm{C}\right)$, in Manora samples in April $\left(282^{\circ} \mathrm{C}\right)$ and in Paradise Point samples in February $\left(540^{\circ} \mathrm{C}\right.$ ) (Table 6). Gel strength was in the range of $111-124 \mathrm{~g} / \mathrm{cm}^{2}$. The highest gel strength was found in Buleji samples $\left(124 \mathrm{~g} / \mathrm{cm}^{2}\right)$ as compared to other studied sites samples (Figure 7). The density of agar extract in $H$. valentiae was in a range of $0.69-1.15 \mathrm{~g} / \mathrm{cm}^{3}$ in all sites samples. It was high in Buleji samples in October $\left(1.10 \mathrm{~g} / \mathrm{cm}^{3}\right)$, in Paradise Point samples in August (1.15 g/ $\left.\mathrm{cm}^{3}\right)$, in Hawks Bay samples in January $(1.00 \mathrm{~g} /$ $\mathrm{cm}^{3}$ ) and in Manora samples in June $\left(1.14 \mathrm{~g} / \mathrm{cm}^{3}\right.$ ) (Table 7). The gel viscosity of $H$. valentiae agar extract was in the range of $79-143$ cP. In Buleji samples viscosity of agar was high in October (143 cP) and in Hawks Bay samples it was high (110 cP) in January whereas in Manora samples viscosity of agar was high in June (128 cP) and in Paradise Point samples viscosity was high in August (108 cP) (Table 7). Gel temperature of $H$. valentiae was in the range of 34 $64^{\circ} \mathrm{C}$. In Buleji samples gel temperature was high in October $\left(55^{\circ} \mathrm{C}\right)$ and in Hawks Bay samples it was high in January $\left(60^{\circ} \mathrm{C}\right)$ whereas in Manora samples it was high in May $\left(64^{\circ} \mathrm{C}\right)$ and in Paradise Point samples gel temperature was high $\left(60^{\circ} \mathrm{C}\right)$ in August (Table 8). $\mathrm{H}$. valentiae gel melting point was in the range of $218-478^{\circ} \mathrm{C}$. Gel melting point was high in October $\left(347^{\circ} \mathrm{C}\right)$ in Buleji samples, in January $\left(300^{\circ} \mathrm{C}\right)$ in Hawks Bay samples, in June $\left(370^{\circ} \mathrm{C}\right)$ in Manora samples and in August $\left(478^{\circ} \mathrm{C}\right)$ in Paradise Point samples (Table 8). Gel strength was in the range of $100-130 \mathrm{~g} / \mathrm{cm}^{2}$. The highest gel strength was found in Manora samples $\left(130 \mathrm{~g} / \mathrm{cm}^{2}\right)$ as compared to other studied sites samples (Figure 7).

\begin{tabular}{|l|c|c|c|c|c|c|c|c|}
\hline Species & \multicolumn{9}{|c|}{ Gel density (gm/cmea musciformis } \\
\hline & \multicolumn{9}{|c|}{} & \multicolumn{4}{c|}{ Gel viscosity (cP) } \\
\hline Sites & Buleji & Hawks Bay & Manora & Paradise Point & Buleji & Hawks Bay & Manora & Paradise Point \\
\hline J & 1.00 & 1.00 & 1.00 & 1.00 & 75 & 98 & 65 & 93 \\
\hline F & 1.17 & 0.93 & 0.84 & 1.22 & 88 & 91 & 54 & 113 \\
\hline M & 0.93 & 1.05 & 1.08 & 1.20 & 70 & 103 & 70 & 111 \\
\hline A & 0.96 & - & 0.89 & 1.25 & 72 & - & 58 & 116 \\
\hline M & 0.90 & - & 0.85 & 1.16 & 67 & - & 55 & 108 \\
\hline J & 0.89 & 0.85 & 0.95 & - & 83 & 83 & 62 & \\
\hline J & 1.09 & 0.82 & 0.98 & - & 82 & 80 & 65 & - \\
\hline A & 1.21 & - & - & - & 91 & - & - & - \\
\hline S & 1.35 & - & 1.05 & 1.44 & 101 & - & 68 & - \\
\hline O & 1.51 & - & 0.72 & 1.22 & 113 & - & 47 & 134 \\
\hline N & 1.24 & 0.85 & 0.70 & 1.16 & 93 & 83 & 45 & 113 \\
\hline D & 1.06 & 1.08 & 0.84 & 1.36 & 79 & 106 & 54 & 108 \\
\hline
\end{tabular}

Table 3: Gel density and gel viscosity of Hypnea musciformis collected from Karachi coast. 
Biochemical Analysis, Yield of Agar and its Physical and Chemical Characteristics of Marine Red Seaweeds of Hypnea musciformis (Wulfen) J. V. Lamouroux, Hypnea pannosa J. Agardh, Hypnea valentiae (Turner) Montagne from Karachi Coast

\begin{tabular}{|c|c|c|c|c|c|c|c|c|}
\hline \multirow{3}{*}{$\begin{array}{c}\text { Species } \\
\text { Sites }\end{array}$} & \multicolumn{8}{|c|}{ Hypnea musciformis } \\
\hline & \multicolumn{4}{|c|}{ Gel temperature $\left({ }^{\circ} \mathrm{C}\right)$} & \multicolumn{4}{|c|}{ Gel melting temperature $\left({ }^{\circ} \mathrm{C}\right)$} \\
\hline & Buleji & Hawks Bay & Manora & Paradise Point & Buleji & Hawks Bay & Manora & Paradise Point \\
\hline $\mathrm{J}$ & 67 & 60 & 55 & 60 & 400 & 360 & 350 & 465 \\
\hline $\mathrm{F}$ & 78 & 56 & 46 & 73 & 469 & 336 & 294 & 568 \\
\hline M & 62 & 63 & 59 & 72 & 374 & 380 & 380 & 559 \\
\hline $\mathrm{A}$ & 64 & - & 49 & 75 & 384 & - & 314 & 583 \\
\hline M & 60 & - & 46 & 70 & 360 & - & 297 & 542 \\
\hline $\mathrm{J}$ & 74 & 51 & 52 & - & 445 & 307 & 334 & - \\
\hline $\mathrm{J}$ & 73 & 49 & 55 & - & 438 & 296 & 355 & - \\
\hline $\mathrm{A}$ & 81 & - & - & - & 485 & - & - & - \\
\hline $\mathrm{S}$ & 90 & - & 57 & 86 & 542 & - & 368 & 671 \\
\hline 0 & 101 & - & 39 & 73 & 607 & - & 253 & 568 \\
\hline $\mathrm{N}$ & 83 & 51 & 38 & 70 & 499 & 307 & 245 & 542 \\
\hline $\mathrm{D}$ & 71 & 65 & 46 & 82 & 425 & 391 & 295 & 635 \\
\hline
\end{tabular}

Table 4: Gel temperature and gel melting temperature of Hypnea musciformis collected from Karachi coast.

\begin{tabular}{|c|c|c|c|c|c|c|c|c|}
\hline Species & \multicolumn{9}{|c|}{ Hypnea pannosa } \\
\hline & \multicolumn{7}{|c|}{ Gel density (gm/cm ${ }^{3}$ ) } & \multicolumn{4}{c|}{ Gel viscosity (cP) } \\
\hline Sites & Buleji & Hawks Bay & Manora & Paradise Point & Buleji & Hawks Bay & Manora & Paradise Point \\
\hline J & 1.04 & 1.00 & 1.07 & 1.00 & 130 & 110 & 112 & 99 \\
\hline F & - & - & 1.17 & 1.21 & - & - & 122 & 120 \\
\hline M & 1.08 & 0.83 & - & 1.11 & 136 & 93 & - & 110 \\
\hline A & 0.96 & 0.83 & 1.44 & 0.95 & 121 & 92 & 150 & 94 \\
\hline M & 1.00 & - & - & 1.00 & 126 & - & - & 99 \\
\hline J & - & - & 1.09 & - & - & - & 114 & - \\
\hline J & - & - & - & - & - & - & - & - \\
\hline A & - & - & - & - & - & - & - \\
\hline S & 0.87 & 0.80 & 0.96 & - & 109 & 88 & 100 & - \\
\hline O & 0.60 & - & 1.08 & - & 75 & - & 113 & - \\
\hline N & 0.58 & 0.83 & 1.00 & 0.95 & 72 & 92 & 105 & - \\
\hline D & 0.69 & - & 1.04 & 0.99 & 87 & - & 108 & 94 \\
\hline
\end{tabular}

Table 5: Gel density and gel viscosity of Hypnea pannosa collected from Karachi coast.

\begin{tabular}{|c|c|c|c|c|c|c|c|c|}
\hline \multirow{3}{*}{$\begin{array}{c}\text { Species } \\
\text { Sites }\end{array}$} & \multicolumn{8}{|c|}{ Hypnea pannosa } \\
\hline & \multicolumn{4}{|c|}{ Gel temperature $\left({ }^{\circ} \mathrm{C}\right)$} & \multicolumn{4}{|c|}{ Gel melting temperature $\left({ }^{\circ} \mathrm{C}\right)$} \\
\hline & Buleji & Hawks Bay & Manora & Paradise Point & Buleji & Hawks Bay & Manora & Paradise Point \\
\hline $\mathrm{J}$ & 51 & 58 & 54 & 63 & 230 & 280 & 210 & 444 \\
\hline $\mathrm{F}$ & - & - & 59 & 76 & - & - & 230 & 540 \\
\hline M & 53 & 49 & - & 70 & 240 & 236 & - & 496 \\
\hline A & 47 & 48 & 72 & 60 & 214 & 234 & 282 & 424 \\
\hline $\mathrm{M}$ & 49 & - & - & 63 & 223 & - & - & 444 \\
\hline $\mathrm{J}$ & - & - & 55 & - & - & - & 214 & - \\
\hline $\mathrm{J}$ & - & - & - & - & - & - & - & - \\
\hline A & - & - & - & - & - & - & - & - \\
\hline $\mathrm{S}$ & 42 & 46 & 48 & - & 192 & 224 & 188 & - \\
\hline 0 & 29 & - & 54 & - & 132 & - & 212 & - \\
\hline $\mathrm{N}$ & 28 & 48 & 50 & 60 & 128 & 234 & 197 & 424 \\
\hline $\mathrm{D}$ & 34 & - & 52 & 62 & 154 & - & 204 & 440 \\
\hline
\end{tabular}

Table 6: Gel temperature and gel melting temperature of Hypnea pannosa collected from Karachi coast. 
Biochemical Analysis, Yield of Agar and its Physical and Chemical Characteristics of Marine Red Seaweeds of Hypnea musciformis (Wulfen) J. V. Lamouroux, Hypnea pannosa J. Agardh, Hypnea valentiae (Turner) Montagne from Karachi Coast

\begin{tabular}{|c|c|c|c|c|c|c|c|c|}
\hline \multirow{3}{*}{$\begin{array}{c}\text { Species } \\
\text { Sites }\end{array}$} & \multicolumn{8}{|c|}{ Hypnea valentiae } \\
\hline & \multicolumn{4}{|c|}{ Gel density $\left(\mathrm{gm} / \mathrm{cm}^{3}\right)$} & \multicolumn{4}{|c|}{ Gel viscosity (cP) } \\
\hline & Buleji & Hawks Bay & Manora & Paradise Point & Buleji & Hawks Bay & Manora & Paradise Point \\
\hline $\mathrm{J}$ & 1.00 & 1.00 & 0.99 & 1.04 & 130 & 110 & 111 & 98 \\
\hline $\mathrm{F}$ & 0.91 & 0.90 & 0.85 & 0.93 & 118 & 99 & 96 & 87 \\
\hline $\mathrm{M}$ & 0.69 & 0.93 & 1.00 & 1.00 & 90 & 102 & 112 & 94 \\
\hline A & 0.91 & - & - & 0.92 & 119 & - & - & 86 \\
\hline M & 0.94 & - & 1.13 & - & 122 & - & 127 & - \\
\hline $\mathrm{J}$ & 0.90 & 0.79 & 1.14 & - & 118 & 87 & 128 & - \\
\hline $\mathrm{J}$ & 0.94 & 0.87 & 1.12 & 1.09 & 122 & 96 & 126 & 103 \\
\hline A & - & - & - & 1.15 & - & - & - & 108 \\
\hline$S$ & 1.02 & - & 0.96 & 0.97 & 133 & - & 108 & 91 \\
\hline 0 & 1.10 & 0.87 & 0.84 & 0.99 & 143 & 96 & 94 & 94 \\
\hline $\mathrm{N}$ & 0.88 & 0.72 & 0.85 & - & 114 & 79 & 96 & - \\
\hline $\mathrm{D}$ & 0.82 & - & 0.84 & 1.02 & 107 & - & 95 & 96 \\
\hline
\end{tabular}

Table 7: Gel density and gel viscosity of Hypnea valentiae collected from Karachi coast.

\begin{tabular}{|c|c|c|c|c|c|c|c|c|}
\hline Species & \multicolumn{9}{|c|}{ Hypnea valentiae } \\
\hline & \multicolumn{9}{|c|}{ Gel temperature $\mathbf{~}^{\circ} \mathbf{C}$ ) } & \multicolumn{4}{c|}{ Gel melting temperature (oC) } \\
\hline Sites & Buleji & Hawks Bay & Manora & Paradise Point & Buleji & Hawks Bay & Manora & Paradise Point \\
\hline J & 50 & 60 & 56 & 55 & 315 & 300 & 321 & 432 \\
\hline F & 45 & 54 & 48 & 49 & 286 & 272 & 278 & 386 \\
\hline M & 34 & 56 & 56 & 53 & 218 & 280 & 325 & 417 \\
\hline A & 45 & - & - & 48 & 289 & - & - & 383 \\
\hline M & 47 & - & 64 & - & 297 & - & 368 & - \\
\hline J & 45 & 47 & 64 & - & 286 & 237 & 370 & \\
\hline J & 47 & 52 & 63 & 57 & 297 & 262 & 268 & - \\
\hline A & - & - & - & 60 & - & - & - & 454 \\
\hline S & 51 & - & 54 & 51 & 323 & - & 312 & 478 \\
\hline O & 55 & 52 & 47 & 52 & 347 & 262 & 274 & 405 \\
\hline N & 44 & 43 & 48 & - & 277 & 217 & 278 & 415 \\
\hline D & 41 & - & 47 & 53 & 260 & - & 275 & - \\
\hline
\end{tabular}

Table 8: Gel temperature and gel melting temperature of Hypnea valentiae collected from Karachi coast.

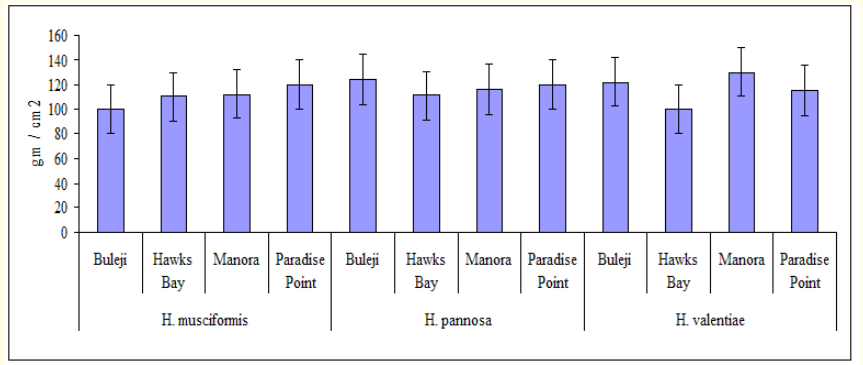

Figure 7: Gel strength in species H. musciformis, H. pannosa and H. valentiae.
The results of FTIR analysis of agar extracted from Hypnea musciformis showed different peak values at $3924.1 \mathrm{~cm}^{-1}, 3851.9 \mathrm{~cm}^{-1}$, $3790.0 \mathrm{~cm}^{-1}, 3447.9 \mathrm{~cm}^{-1}, 2925.0 \mathrm{~cm}^{-1}$ and $2851.1 \mathrm{~cm}^{-1}$ for functional groups alcohols, amines and alkanes (O-H, N-H, C-H), $2273.5 \mathrm{~cm}^{-1}$ for alkynes and nitriles $(\mathrm{C} \equiv \mathrm{C}, \mathrm{C} \equiv \mathrm{N}), 1645.2 \mathrm{~cm}^{-1}$ and $1644.2 \mathrm{~cm}^{-1}$, $1554.1 \mathrm{~cm}^{-1}$, for carbonyl amide, nitro methane and aromatic $\mathrm{C}=0$, $\mathrm{N}=0$ ), $1451.2 \mathrm{~cm}^{-1}$ for alkane (C-C), $1161.2 \mathrm{~cm}^{-1}$ and $1080.6 \mathrm{~cm}^{-1}$ for sulfoxides ( $\mathrm{S}=0$ ), $930.0 \mathrm{~cm}^{-1}, 846.3 \mathrm{~cm}^{-1}$ and $705.4 \mathrm{~cm}^{-1}$ for alkene (C-H), $604.4 \mathrm{~cm}^{-1}$ for alkyl halide (C-Cl) (Figure 8 and table 9). The results of FTIR analysis of agar extracted from $H$. pannosa showed different peak values at $3413.8 \mathrm{~cm}^{-1}, 2925.8 \mathrm{~cm}^{-1}, 2860.2 \mathrm{~cm}^{-1}$ and $2520.8 \mathrm{~cm}^{-1}$ for functional groups alcohols, amines and alkanes $(0$ - 
Biochemical Analysis, Yield of Agar and its Physical and Chemical Characteristics of Marine Red Seaweeds of Hypnea musciformis (Wulfen) J. V. Lamouroux, Hypnea pannosa J. Agardh, Hypnea valentiae (Turner) Montagne from Karachi Coast

H, N-H, C-H), $1645.2 \mathrm{~cm}^{-1}$, carbonyl amide, nitro methane and aromatic ( $\mathrm{C}=0, \mathrm{~N}=0), 1429.2 \mathrm{~cm}^{-1}$ for alkane (C-C), $1259.4 \mathrm{~cm}^{-1}$ aliphatic amines (C-N), $1157.2 \mathrm{~cm}^{-1}$ and $1076.2 \mathrm{~cm}^{-1}$ for sulfoxides (S $=0), 871.8 \mathrm{~cm}^{-1}, 783.0 \mathrm{~cm}^{-1}$ and $707.8 \mathrm{~cm}^{-1}$ for alkene $(\mathrm{C}-\mathrm{H}), 673.1$ $\mathrm{cm}^{-1}$ for alkyl halide (C-Cl), $459.0 \mathrm{~cm}^{-1}$ alkyl halide (C-I) (Figure 9 and table 10). The results of FTIR analysis of agar extracted from H. valentiae showed different peak values at $3962.7 \mathrm{~cm}^{-1}, 3903.7$ $\mathrm{cm}^{-1}, 3855.0 \mathrm{~cm}^{-1}, 3810.8 \mathrm{~cm}^{-1}, 3754.0 \mathrm{~cm}^{-1}, 3675.3 \mathrm{~cm}^{-1}, 3527.8 \mathrm{~cm}$ ${ }^{1}, 3492.9 \mathrm{~cm}^{-1}, 3418.0 \mathrm{~cm}^{-1}, 2926.3 \mathrm{~cm}^{-1}$ and $2855.5 \mathrm{~cm}^{-1}$ for functional groups alcohols, amines and alkanes (O-H, N-H, C-H), 2273.4 $\mathrm{cm}^{-1}$ for alkynes and nitriles $(\mathrm{C} \equiv \mathrm{C}, \mathrm{C} \equiv \mathrm{N}), 1742.6 \mathrm{~cm}^{-1}, 1643.9 \mathrm{~cm}^{-1}$, $1555.9 \mathrm{~cm}^{-1}$ and $1508.3 \mathrm{~cm}^{-1}$ for carbonyl amide, nitro methane and aromatic ( $\mathrm{C}=0, \mathrm{~N}=0$ ), $1461.1 \mathrm{~cm}^{-1}$ for alkane (C-C), $1372.9 \mathrm{~cm}^{-1}$ for alkane and nitro methane ( $\mathrm{C}-\mathrm{N}, \mathrm{N}=0), 1242.5 \mathrm{~cm}^{-1}$ for aliphatic amines (C-N), $1165.3 \mathrm{~cm}^{-1}, 1085.5 \mathrm{~cm}^{-1}$ and $1037.9 \mathrm{~cm}^{-1}$ for sulfoxides ( $\mathrm{S}=0), 701.8 \mathrm{~cm}^{-1}$ for alkene $(\mathrm{C}-\mathrm{H}), 559.7 \mathrm{~cm}^{-1}$ for alkyl halide (C-Cl), $474.0 \mathrm{~cm}^{-1}$ for alkyl halide (C-I) (Figure 10 and table 11).

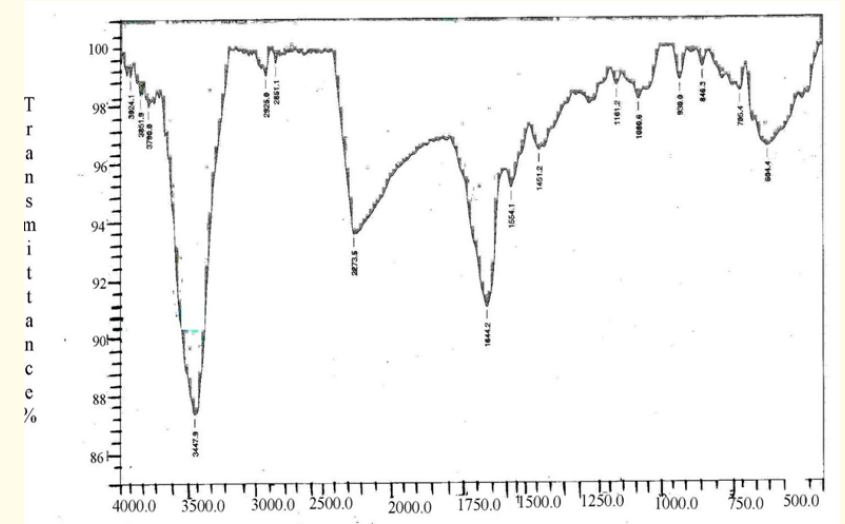

Wavenumber $\mathrm{cm}^{-1}$

Figure 8: FTIR spectrum of agar in specie of Hypnea musciformis.

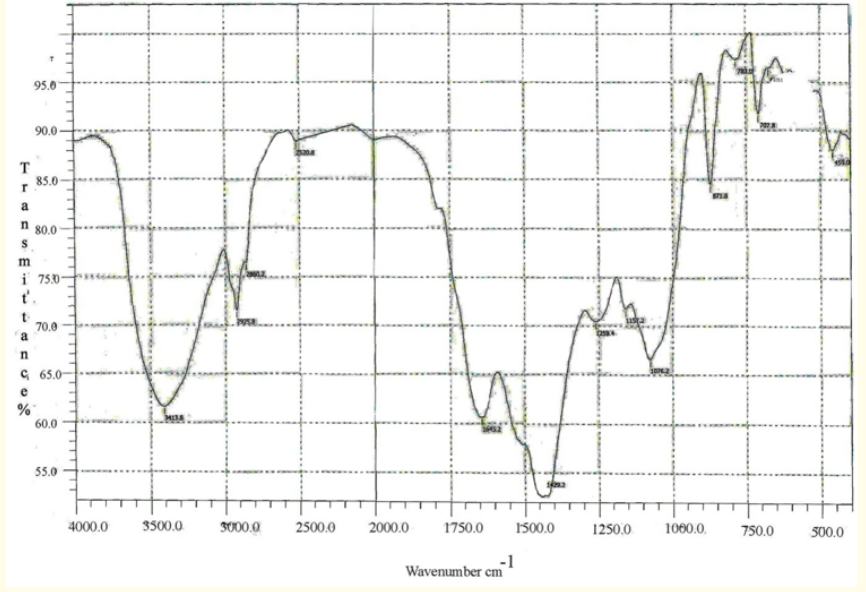

Figure 9: FTIR spectrum of agar in specie of Hypnea pannosa.

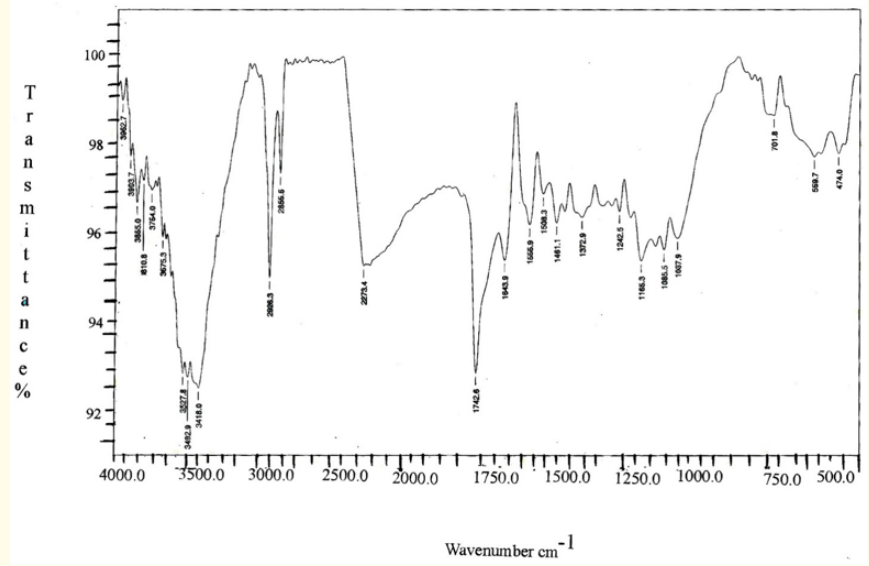

Figure 10: FTIR spectrum of agar in specie of Hypnea valentiae.

\begin{tabular}{|c|c|c|c|c|c|c|}
\hline $\begin{array}{l}\text { IR Frequency } \\
\left(\mathrm{cm}^{-1}\right)\end{array}$ & Bond & Functional group & Intensity Estimation & $\begin{array}{c}\text { Type of } \\
\text { Vibration }\end{array}$ & $\begin{array}{l}\text { Sample IR Frequency } \\
\left(\mathrm{cm}^{-1}\right)\end{array}$ & Reference \\
\hline $4000-2500$ & $\mathrm{O}-\mathrm{H}, \mathrm{N}-\mathrm{H}, \mathrm{C}-\mathrm{H}$ & Alcohol, Amine, Alkane & Strong, Sharp & $\begin{array}{l}\text { Stretch, } \\
\text { Free }\end{array}$ & $\begin{array}{l}3924.1,3851.9,3790.0 \\
3447.9,2925.0,2851.1\end{array}$ & [17-19] \\
\hline $2500-2000$ & $\mathrm{C} \equiv \mathrm{C}, \mathrm{C} \equiv \mathrm{N}$ & Alkyne, Nitriles & Medium & Stretch & 2273.5 & [17] \\
\hline $2000-1500$ & $\mathrm{C}=0, \mathrm{~N}=\mathrm{O}$ & $\begin{array}{c}\text { Cabonyl Amide, Nitro, } \\
\text { Aromatic }\end{array}$ & $\begin{array}{c}\text { Very weak, medium, } \\
\text { Strong }\end{array}$ & Stretch & $1644.2,1554.1$ & {$[17,18,20]$} \\
\hline $1500-1400$ & $\mathrm{C}-\mathrm{C}$ & Alkane & Medium to Weak & Stretch & 1451.2 & [18] \\
\hline $1200-1000$ & $S=0$ & Sulfoxides & Strong & Stretch & $1161.2,1080.6$ & {$[20]$} \\
\hline $1000-700$ & $\mathrm{C}-\mathrm{H}$ & Alkene & Weak & Bending & $930.0,846.3,705.4$ & {$[20]$} \\
\hline $700-500$ & $\mathrm{C}-\mathrm{Cl}$ & Alkyl Halide & Strong & Stretch & 604.4 & {$[17,20]$} \\
\hline
\end{tabular}

Table 9: FTIR absorption frequency $\left(\mathrm{cm}^{-1}\right)$, intensity estimation and functional group of agar extracted from Hypnea musciformis. 
Biochemical Analysis, Yield of Agar and its Physical and Chemical Characteristics of Marine Red Seaweeds of Hypnea musciformis (Wulfen) J. V. Lamouroux, Hypnea pannosa J. Agardh, Hypnea valentiae (Turner) Montagne from Karachi Coast

\begin{tabular}{|c|c|c|c|c|c|c|}
\hline $\begin{array}{l}\text { IR Frequency } \\
\qquad\left(\mathrm{cm}^{-1}\right)\end{array}$ & Bond & Functional group & Intensity Estimation & $\begin{array}{c}\text { Type of } \\
\text { Vibration }\end{array}$ & $\begin{array}{c}\text { Sample IR Frequen- } \\
\text { cy }\left(\mathrm{cm}^{-1}\right)\end{array}$ & Reference \\
\hline $4000-2500$ & $\mathrm{O}-\mathrm{H}, \mathrm{N}-\mathrm{H}, \mathrm{C}-\mathrm{H}$ & Alcohol, Amine, Alkane & Strong, Sharp & Stretch, Free & $\begin{array}{l}3413.8,2925.8 \\
2860.2,2520.8\end{array}$ & [17-19] \\
\hline $2000-1500$ & $\mathrm{C}=0, \mathrm{~N}=\mathrm{O}$ & $\begin{array}{c}\text { Cabonyl Amide, Nitro, } \\
\text { Aromatic }\end{array}$ & $\begin{array}{c}\text { Very weak, medium, } \\
\text { Strong }\end{array}$ & Stretch & 1645.2 & {$[17,18,20]$} \\
\hline $1500-1400$ & $\mathrm{C}-\mathrm{C}$ & Alkane & Medium to Weak & Stretch & 1429.2 & [18] \\
\hline $1300-1200$ & $\mathrm{C}-\mathrm{N}$ & Aliphatic Amines & Strong & Stretch & 1259.4 & {$[17,18,20]$} \\
\hline $1200-1000$ & $S=0$ & Sulfoxides & Strong & Stretch & $1157.2,1076.2$ & [20] \\
\hline $1000-700$ & $\mathrm{C}-\mathrm{H}$ & Alkene & Weak & Bending & $871.8,783.0,707.8$ & {$[20]$} \\
\hline $700-500$ & $\mathrm{C}-\mathrm{Cl}$ & Alkyl Halide & Strong & Stretch & 673.1 & {$[17,20]$} \\
\hline $200-500$ & $\mathrm{C}-\mathrm{I}$ & Alkyl Halide & Strong & Stretch & 459.0 & {$[17,20]$} \\
\hline
\end{tabular}

Table 10: FTIR absorption frequency $\left(\mathrm{cm}^{-1}\right)$, intensity estimation and functional group of agar extracted from Hypnea pannosa.

\begin{tabular}{|c|c|c|c|c|c|c|}
\hline $\begin{array}{l}\text { IR Frequency } \\
\left(\mathrm{cm}^{-1}\right)\end{array}$ & Bond & Functional group & $\begin{array}{l}\text { Intensity } \\
\text { Estimation }\end{array}$ & $\begin{array}{c}\text { Type of } \\
\text { Vibration }\end{array}$ & $\begin{array}{l}\text { Sample IR Frequency } \\
\left(\mathrm{cm}^{-1}\right)\end{array}$ & Reference \\
\hline $4000-2500$ & $\mathrm{O}-\mathrm{H}, \mathrm{N}-\mathrm{H}, \mathrm{C}-\mathrm{H}$ & Alcohol, Amine, Alkane & Strong, Sharp & Stretch, Free & $\begin{array}{c}3962.7,3903.7,3855.0 \\
3810.8,3754.0,3675.3, \\
3527.8,3492.9,3418.0, \\
2926.3,2855.5\end{array}$ & [17-19] \\
\hline $2500-2000$ & $\mathrm{C} \equiv \mathrm{C}, \mathrm{C} \equiv \mathrm{N}$ & Alkyne, Nitriles & Medium & Stretch & 2273.4 & {$[17]$} \\
\hline $2000-1500$ & $\mathrm{C}=\mathrm{O}, \mathrm{N}=\mathrm{O}$ & $\begin{array}{c}\text { Carbonyl Amide, Nitro, } \\
\text { Aromatic }\end{array}$ & $\begin{array}{c}\text { Very weak, } \\
\text { medium, Strong }\end{array}$ & Stretch & $\begin{array}{c}1742.6,1643.9,1555.9 \\
1508.3\end{array}$ & {$[17,18,20]$} \\
\hline $1500-1400$ & $\mathrm{C}-\mathrm{C}$ & Alkane & Medium to Weak & Stretch & 1461.1 & [18] \\
\hline $1400-1300$ & $\mathrm{C}-\mathrm{N}, \mathrm{N}=\mathrm{O}$ & Alkane, Nitro methane & Medium & Bending & 1372.9 & {$[18,20]$} \\
\hline $1300-1200$ & $\mathrm{C}-\mathrm{N}$ & Aliphatic Amines & Strong & Stretch & 1242.5 & {$[17,18,20]$} \\
\hline $1200-1000$ & $S=0$, & Sulfoxides & Strong & Stretch & $1165.3,1085.5,1037.9$ & {$[20]$} \\
\hline $1000-700$ & $\mathrm{C}-\mathrm{H}$ & Alkene & Weak & Bending & 701.8 & {$[20]$} \\
\hline $700-500$ & $\mathrm{C}-\mathrm{Cl}$, & Alkyl Halide & Strong & Stretch & 559.7 & {$[17,20]$} \\
\hline $200-500$ & $\mathrm{C}-\mathrm{I}$ & Alkyl Halide & Strong & Stretch & 474.0 & {$[17,20]$} \\
\hline
\end{tabular}

Table 11: FTIR absorption frequency $\left(\mathrm{cm}^{-1}\right)$, intensity estimation and functional group of agar extracted from Hypnea valentiae.

The carbohydrate content in $\mathrm{H}$. musciformis was in the range of $20-25 \%$ with mean concentration value of $23.12 \pm 2.39 \%$. The highest content of carbohydrate (25\%) was obtained from Manora samples as compared to other sites samples (Figure 11). The ash content in H. musciformis was in the range of $10-20 \%$ with mean concentration value of $15 \pm 4.08 \%$. The highest content of ash $(20 \%)$ was also obtained in Manora samples as compared to other sites samples (Figure 11). The carbohydrate content in H. pannosa was in the range of $26.25-30 \%$ with mean concentration value of $27.9 \pm 1.55 \%$. The highest (30\%) content of carbohydrate was obtained from Buleji sample as compared to other sites samples (Figure 12). The ash content in H. pannosa was in the range of 15 - $18.33 \%$ with mean concentration value of $17.70 \pm 2.08 \%$. The highest content of ash (18.33\%) was obtained from Paradise Point sample as compared to other sites samples (Figure 12). The carbo- hydrate content in $H$. valentiae was in the range of $20-25 \%$ with mean concentration value of $21.70 \pm 2.25 \%$. The highest $(25 \%)$ content of carbohydrate was obtained from Paradise Point sample as compared to other sites samples (Figure 13). The ash content in $H$. valentiae was in the range of $10-12.5 \%$ with mean concentration value of $11.25 \pm 1.02 \%$. The highest content of ash $(12.5 \%)$ was obtained from Hawks Bay samples as compared to other sites samples (Figure 13).

The results of two way analysis of variance (ANOVA) in agar gel content of three species $H$. musciformis, $H$. pannosa and $H$. valentiae showed that there were highly significant variations observed between species $(\mathrm{P}<0.05)$, month $(\mathrm{P}<0.001)$ and sites $(\mathrm{P}<0.01)$. The differences in species, sites and month in present results reveal that agar content was different in all three studied species at dif- 


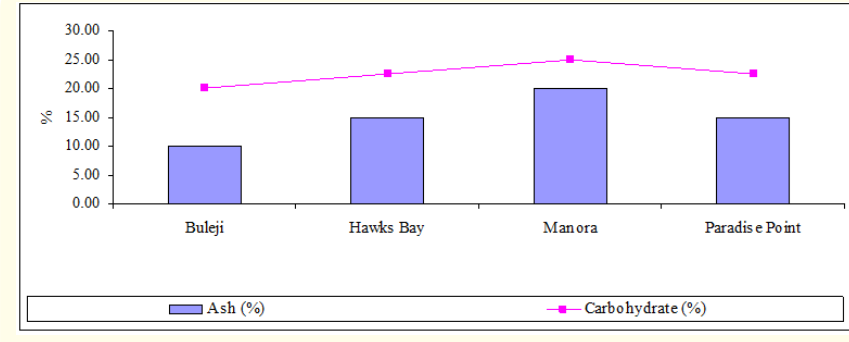

Figure 11: Carbohydrate and ash content in Hypnea musciformis of Karachi coast.

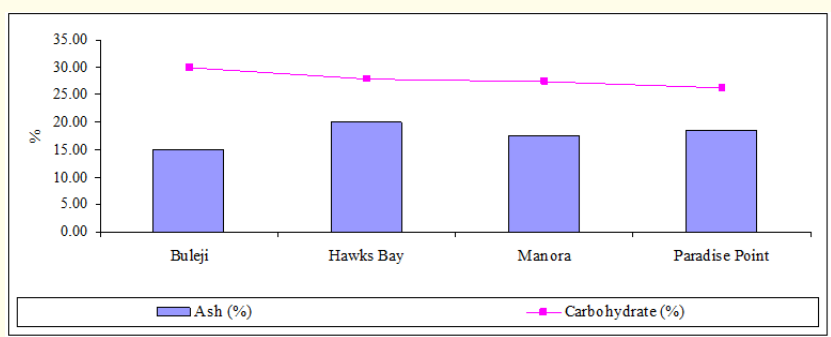

Figure 12: Carbohydrate and ash content in Hypnea pannosa of Karachi coast.

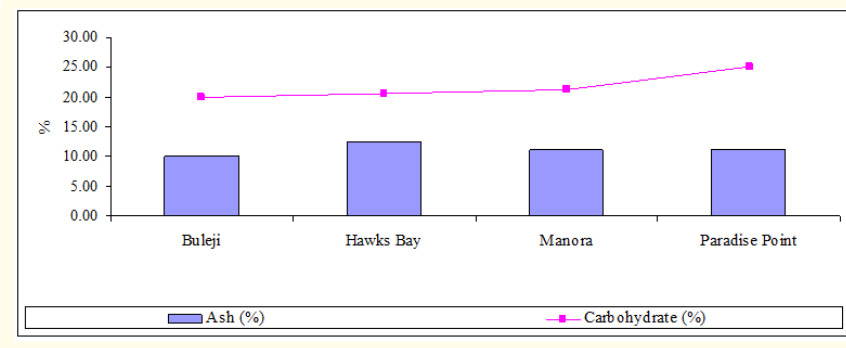

Figure 13: Carbohydrate and ash content in Hypnea valentiae of Karachi coast. ferent sites in different times (Table 12). The data for agar concentrations of the three experimental species used in this study were analyzed to determine the relationship in between agar of the three species of Hypnea at different sites found. Positive significant correlation were found in agar of $H$. musciformis and $H$. valentiae collected from Hawks Bay $\left(r^{2}=0.604\right)$ and Manora $\left(r^{2}=0.660\right)$ and H. musciformis and H. pannosa collected from Paradise Point $\left(\mathrm{r}^{2}=\right.$ 0.600). The insignificant correlation was found in between agar, carbohydrate and ash content.

The present study demonstrated that the yield of agar varied seasonally (time of collection) species to species. The results for yield of agar extracted from the species of $\mathrm{H}$. musciformis (17.80 $30 \%)$, H. pannosa (22 - 35.80\%) and H. valentiae (20.80 - 35\%) in present work were high to the values reported by Fathy and Mohammady [6] from Mediterranean seashore of Alexandria, Egypt for the $H$. musciformis (15.3 - 24\%). The highest yield was due to temperature and photoperiod [14]. The maximum and minimum yield of agar obtained in present work in the same period reported by Fathy and Mohammady [6].

In the present work variations were found in physical properties in between all three species indicates that season and environment affect on the physical properties of agar like the quantity of agar [15]. The present work showed that the highest gel density was obtained in Hypnea musciformis whereas the highest gel viscosity was obtained in Hypnea valentiae as compared to other species. It is also noted that the highest gel boiling temperature $\left(101^{\circ} \mathrm{C}\right)$ in October and gel melting temperature $\left(671^{\circ} \mathrm{C}\right)$ was obtained in Hypnea musciformis from the samples of Buleji and Paradise Point respectively. High viscosity and melting temperature values indicate a high molecular weight polymer [16]. Gel temperature of $H$. musciformis $\left(38-101^{\circ} \mathrm{C}\right.$ ) and the gel melting temperatures of all studied Hypnea species $\mathrm{H}$. musciformis $\left(360-499^{\circ} \mathrm{C}\right)$, H. pannosa $\left(128-540^{\circ} \mathrm{C}\right)$ and $H$. valentiae $\left(218-478^{\circ} \mathrm{C}\right)$ were high whereas

\begin{tabular}{|c|c|c|c|c|c|c|}
\hline Source & DF & Seq SS & Adj SS & Adj MS & F & P \\
\hline Month & 11 & 4188.8 & 4181.8 & 380.2 & $3.50^{* * *}$ & 0.000 \\
\hline Sites & 3 & 1548.2 & 1562.8 & 520.9 & $4.80^{* *}$ & 0.003 \\
\hline Species & 2 & 801.0 & 801.0 & 400.5 & $3.69^{*}$ & 0.028 \\
\hline Error & 127 & 13793.5 & 13793.5 & 108.6 & & \\
\hline Total & 143 & 20331.5 & & & & \\
\hline
\end{tabular}

Table 12: Analysis of variance (ANOVA) for yield of agar in different species of Hypnea

(H. musciformis, H. pannosa, $H$. valentiae) at four different sites of Karachi coast.

Note: ${ }^{*}=$ significant at $\mathrm{P}<0.05,^{* *}=$ significant at $\mathrm{P}<0.01$ and ${ }^{* * *}=$ significant at $\mathrm{P}<0.001$ 
Biochemical Analysis, Yield of Agar and its Physical and Chemical Characteristics of Marine Red Seaweeds of Hypnea musciformis (Wulfen) J. V. Lamouroux, Hypnea pannosa J. Agardh, Hypnea valentiae (Turner) Montagne from Karachi Coast

gel strength of $H$. musciformis (100 - $\left.120 \mathrm{~g} / \mathrm{cm}^{2}\right), H$. pannosa (111 $\left.-124 \mathrm{~g} / \mathrm{cm}^{2}\right)$ and $H$. valentiae $\left(100-130 \mathrm{~g} / \mathrm{cm}^{2}\right)$ values were found lower when compared with the previous study for the H. musciformis from Mediterranean seashore of Alexandria, Egypt [6].

The results of FTIR analysis of agar extract showed strong and sharp absorption peaks in the 2520.8 - $3962.7 \mathrm{~cm}^{-1}$ region (Alcohol, Amine, Alkane), 1242.5 - $1259.4 \mathrm{~cm}^{-1}$ (Aliphatic Amines), 1037.9 - $1161.2 \mathrm{~cm}^{-1}$ Sulfoxides) and $559.7-673.1 \mathrm{~cm}^{-1}$ (Alkyl Halide) region in all agar samples [17-20]. The absorbance peak at 701.8 - $930.0 \mathrm{~cm}^{-1}$ representing bending vibration of $\mathrm{C}-\mathrm{H}$ group indicated the presence of amino acids [21]. The absorbance peak of medium band observed at $2273.4 \mathrm{~cm}^{-1}$ representing the stretching vibration of $\mathrm{C} \equiv \mathrm{C}$ group. The carboxyl and hydroxyl functional groups are mainly found in polysaccharides and are primary constituent of seaweeds found in all studied samples can be used in medicine [2]. The other chemical groups are characteristic of present agar samples are Alkyne, Nitriles, Carbonyl Amide, Nitro, Aromatic alkane, alkane nitro methane and alkene $[17,18,20,22]$. The types of vibration were mostly stretch free, stretch and bending.

The carbohydrate and ash content in H. musciformis, H. pannosa and $H$. valentiae in the present study was low when compared with the previous study reported by Abbas., et al. [23] from Buleji and Sandspit of Karachi coast. The carbohydrate content of $\mathrm{H}$. musciformis in the present work was also low when compared with another previous study reported by El-Said and El-Sikaily [24] from Egypt but it was high when compared with same specie reported by Manivannan., et al. [25] from South east coast of India.

\section{Conclusion}

The results from our study suggest that the agar extracted from H. musciformis, H. pannosa and H. valentiae found on our coast could be considered for further studies which are useful for pharmaceutical industries. From the review of studies we concluded that marine environment possess many living resources but In Pakistan still we do not get benefits from the resources of seaweed, we should to utilize and take advantage from these resources.

\section{Acknowledgement}

Authors wish to express sincere thanks to Department of Chemistry, University of Karachi and pharmaceutical companies for providing laboratory facilities. Author Rashida Qari is grateful to Higher Education Commission of Pakistan for providing financial support throughout the study period.

\section{Bibliography}

1. Kaliaperumal N., et al. "Seasonal changes in growth, biochemical constituents and phycocolloid of some marine algae of Mandapam coast". Seaweed Research and Utilisation 24.1 (2002): 73-77.
2. Kannan S. "FT-IR and EDS analysis of the seaweeds Sargassum wightii (brown algae) and Gracilaria corticata (red algae)". International Journal of Current Microbiology and Applied Sciences 3.4 (2014): 341-351.

3. Hussein MH. "Extraction of agar from Gelidium sp. (Rhodophyta) and green synthesis of agar/silver nanoparticles". Journal of Agricultural Chemistry and Biotechnology Mansoura University 6.10 (2015): 419-434.

4. Mohammed G. "Farming of Hypnea valentiae (Turner) Montagne at Minicoy Lagoon (Lakshadweep)". Seaweed Research Utiln 27.1-2 (2005): 93-98.

5. Villanueva RD., et al. "Agar from the red seaweed, Laurencia flexilis (Ceramiales, Rhodophyta) from northern Philippines". Phycological Research 58 (2010): 151-156.

6. Fathy AA and Mohammady NG. "Seasonal variation on biomass and agar quality extracted from the Marine red algae Pterocladia capillacea and Hypnea musciformis growing along Mediterranean seashore of Alexandria, Egypt". Egyptian Journal of Phycology 8 (2007): 29-38.

7. Qari R., et al. "Carrageenan content in three species of Hypnea (H. musciformis Wulfen J. V. Lamouroux, H. pannosa J. Agardh and H. Valentiae Turner Montagne) of Karachi coast". International Journal of Marine Science 8.11 (2018): 89-100.

8. Mouradi A., et al. "Seasonal variation of the growth, chemical composition and carrageenan extracted from Hypnea musciformis (Wulfen) Lamouroux harvested along the Atlantic coast of Morocco". Scientific Research and Essay 2.10 (2008): 509. 514.

9. Praiboon J., et al. "Physical and chemical characterization of agar polysaccharides extracted from the Thai and Japanese species of Gracilaria". Sciences Asia 1 (2006): 11-17.

10. Whyte JNC and Englar JR. "Chemical composition and quality of agars in morphotypes of Gracilaria from British Columbia". Bot 23 (1980): 277-283

11. Mohan J. "Organic spectroscopy principles and applications". $2^{\text {nd }}$ Edition, Narosa publishing House, Daryagani, Delhi (2005).

12. Dubois M., et al. "Calorimetric method for determination of sugars and related substances". Analytical Chemistry 28 (1956): 350-356. 
13. A.O.A.C. "Official methods of analysis of association of official analytical chemists". Association Official Analytical Chemists. Arlington, VA (1990).

14. Nil S., et al. "Effects of season on the yield and quality of agar from Gelidium sesquipedale (Rhodophyta) from Mostaganem, Algeria". African Journal of Biotechnology 15.10 (2016): 350355.

15. Marinho-Soriano E and Bourret E. "Effects of season on the yield and quality of agar from Gracilaria species (Gracilariaceae, Rhodophyta)". Bioresource Technology 90 (2003): 329333.

16. Whyte JNC., et al. "Seasonal variations in the biomass, quantity and quality of agar from the reproductive and vegetative stages of Gracilaria verrucosa type". Botanica Marina 24 (1981): 493-501.

17. Faust B. "Modern Chemical Techniques: An Essential Reference for Students and Teachers". The Royal Society of Chemistry, Unilever 5 (1997): 127-128.

18. Radhika D and Mohaideen A. "Fourier Transform Infrared analysis of Ulva lactuca and Gracilaria corticata and their effect on antibacterial activity". Asian Journal of Pharmaceutical and Clinical Research 8.2 (2015): 209-212.

19. Fernando IPS., et al. "FTIR characterization and antioxidant activity of water soluble crude polysaccharides of Sri Lankan marine algae". Algae 32.1 (2017): 75-86.

20. Pavia DL, et al. "Introduction to Spectroscopy". Brooks/Cole, Cengage Learning, Fourth Edition (2009): 511.

21. Rao CNR. "Chemical applications of infrared spectroscopy". Academic Press, New York and London (1963): 391.

22. Diaz, RA., et al. "Characterization of polysaccharides from Hypnea spinella (Gigartinales) and Halopithys incurva (Ceramiales) and their effect on RAW 264.7 macrophage activity". Journal of Applied Phycology 23.3. (2010): 1-6.

23. Abbas Q., et al. "Biochemical composition of seaweeds after the oil spill from Tasman Spirit at the coast of Karachi". In: Climate change and Island and coastal vulnerability. Sundaresan J., Sreekesh, S., Ramanathan, Al., Sonnenschein, L. and Boojh, R., editions. Copublished by Springer, Netherlands with Capital Publishing Company, New Delhi, India (2013): 154-165.
24. El-Said GF and El-Silaily A. "Chemical composition of some seaweed from Mediterranean Sea coast, Egypt". Environmental Monitoring and Assessment 185 (2013): 6089-6099.

25. Manivannan K., et al. "Proximate Composition of Different Group of Seaweeds from Vedalai Coastal Waters (Gulf of Mannar): Southeast Coast of India". Middle-East Journal of Scientific Research 4.2 (2009): 72-77.

\section{Assets from publication with us}

- Prompt Acknowledgement after receiving the article

- Thorough Double blinded peer review

- Rapid Publication

- Issue of Publication Certificate

- High visibility of your Published work

Website: https://www.actascientific.com/

Submit Article: https://www.actascientific.com/submission.php Email us: editor@actascientific.com

Contact us: +919182824667 